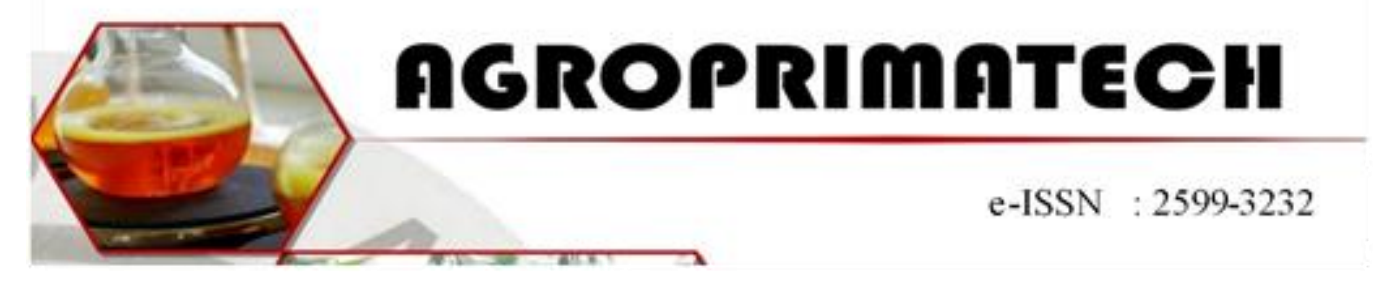

\title{
MODEL KESESUAIAN HABITAT ORANGUTAN KALIMANTAN (Pongo pygmaeus wurmbii, Linneaus 1760) DI SUAKA MARGASATWA SUNGAI LAMANDAU KALIMANTAN TENGAH
}

\author{
FIFIN FITRIANA ${ }^{1}$, LILIK BUDI PRASETYO², DONES RINALDI ${ }^{3}$ \\ 1) Universitas Muhammadiyah Bangka Belitung \\ 3,2) Departemen Konservasi Sumberdaya Hutan dan Ekowisata Fakultas Kehutanan IPB \\ E-mail : fifin.fitriana@unmuhbabel.ac.id
}

\begin{abstract}
ABSTRAK
Orangutan kalimantan (Pongo pygmaeus wurmbii) termasuk ke dalam flagship species dan merupakan satwa langka yang keberadaannya dilindungi sepenuhnya oleh perundang-undangan di Indonesia. Hal ini disebabkan karena ancaman terhadap habitat maupun populasi yang tinggi. Suaka Margasatwa Sungai Lamandau merupakan habitat orangutan kalimantan dan memiliki nilai penting karena merupakan lokasi pelepasliaran orangutan kalimantan rehabilitasi. Oleh karena itu, model kesesuaian habitat orangutan kalimantan sangat diperlukan sebagai dasar untuk manajemen habitat orangutan di Suaka Margasatwa Sungai Lamandau. Pemodelan kesesuaian habitat orangutan kalimantan dilakukan dengan mengidentifikasi titik sarang orangutan kalimantan secara spasial terhadap faktor habitat yaitu jarak dengan sungai dan nilai NDVI (Normalized Difference Vegetation), dan faktor gangguan yaitu jarak dengan jalan dan jarak dengan desa. Hasil identifikasi dianalisis menggunakan Principal Componen Anayisis (PCA) kemudian diekstrapolasikan ke dalam bentuk peta. Model kesesuaian habitat orangutan kalimantan yang diperoleh adalah $Y=(1,747 x \mathrm{xJarak}$ dengan Sungai $)+(1,747$ xNilai NDVI $)+(1,215 x$ Jarak dengan Jalan $)+(1,215 x J a r a k$ dengan Desa). Kesesuaian habitat orangutan kalimantan dibagi menjadi tiga kelas yaitu kelas kesesuaian rendah 6311,70 ha atau $7,88 \%$ dari keseluruhan luas lokasi penelitian, kelas kesesuaian sedang 52378,7 ha atau $65,46 \%$ dari keseleruhan luas lokasi penelitian dan kelas kesesuaian tinggi 21328,6 ha atau $26,65 \%$ dari keseluruhan luas lokasi penelitian. Validasi untuk tingkat kelas kesesuaian rendah $0 \%$, kelas kesesuaian sedang 60,87\% dan kelas kesesuaian tinggi $39,13 \%$. Model kesesuaian habitat orangutan kalimantan dapat diterima dengan validasi $100 \%$ pada kelas kesesuaian sedang dan tinggi.
\end{abstract}

Kata kunci : Orangutan Kalimantan, (Pongo pygmaeus wurmbii), Kesesuaian, Habitat, Orangutan

\section{PENDAHULUAN}

SM Sungai Lamandau merupakan kawasan konservasi yang menjadi habitat bagi orangutan kalimantan dan memiliki nilai penting karena merupakan salah satu kawasan yang digunakan sebagai lokasi pelepasliaran orangutan rehabilitasi (Fitriana, 2011). SM Lamandau terletak di Kabupaten Kotawaringin Barat dan Kabupaten Sukamara dengan luas kawasan \pm 76.110 ha berdasarkan penunjukan SK Menteri Kehutanan
Nomor:162/Kpts-II/1998 tanggal 26 Februari 1998 (Sosilawati et al, 2020).

Orangutan tergolong primata langka (Anthony \& Nayman, 1978) yang keberadaannya hanya terdapat di Asia (Galdikas, 1978). Saat ini orangutan Kalimantan telah dilindungi oleh pemerintah melalui PP No.7 Tahun 1999 dan termasuk kedalam satwa dengan status kritis (Critically Endangered) yang merupakan status ancaman kepunahan tertinggi menurut IUCN Red List. Orangutan kalimantan juga terdaftar dalam 
APPENDIX 1 CITES (Convention International of Trade Endangered Spesies of Wild Fauna and Flora). Status tersebut disebabkan karena kecenderungan penurunan populasi orangutan kalimantan diakibatkan degradasi lingkungan, konversi lahan, kebakaran hutan, perburuan dan perdagangan. Secara ekologi, orangutan kalimantan merupakan "umbrella species" yang berperan penting dalam pemencaran biji-biji dari tumbuhan yang dikonsumsinya. Oleh sebab itu, ketidakhadiran orangutan di hutan hujan tropis dapat mengakibatkan kepunahan suatu jenis tumbuhan (Fitriana, 2011).

Pentingnya keberadaan orangutan dan banyaknya tekanan terhadap habitat orangutan, maka upaya konservasi sangat diperlukan untuk menjaga kelestarian orangutan. Upaya konservasi sangat dibutuhkan untuk menjamin kelestarian jenis (Fitriana et al, 2016), salah satunya dengan mengetahui kondisi habitat. Informasi yang diperlukan dalam upaya konservasi orangutan kalimantan di SM Sungai Lamandau adalah model kesesuaian habitat orangutan kalimantan, mengingat SM Sungai Lamandau merupakan tempat pelepasliaran orangutan yang telah direhabilitasi. Adanya informasi model kesesuaian habitat dapat menjadi data dasar dalam pengelolaan (Fitriana, 2016), serta sebagai dasar dari pengambilan langkah lanjutan untuk menjaga habitat orangutan kalimantan sebagai satwa penting di SM Sungai Lamandau.

\section{Metode Penelitian}

Penelitian ini dilakasanakan di SM Sungai Lamandau dan di lokasi usulan zona pemanfaatan (zona buffer) terbatas SM Sungai Lamandau Kalimantan Tengah. Pengambilan data lapang dilaksanakan pada bulan Agustus 2011. Jenis data yang dikumpulkan meliputi data keberadaan orangutan dan data karakteristik habitat yang mencakup faktor habitat dan gangguan.

Jenis data yang dikumpulan meliputi data primer yaitu titik perjumpaan dan titik sarang orangutan kalimantan, peta jaringan jalan, peta jaringan sungai, peta administratif kalimantan tengah dan citra landsat TM, serta data sekunder yaitu data bio-ekologi orangutan kalimantan dan data kondisi umum lokasi penelitian. Titik perjumpaan dan titik sarang diperoleh dengan metode line transect dan data sekunder diperoleh dengan studi literatur, observasi lapang, wawancara kepada pengunjung, pengelola dan mayarakat.

Penyusunan pemodelan spasial habitat orangutan Kalimantan ini dimulai dengan mengumpulkan data primer dan data sekunder. Data input bersumber pada peta digital diperoleh dari analisis peta dan observasi lapang. Proses analisis peta ini akan menghasilkan 4 peta tematik (layer) yang digunakan dalam pemodelan spasial habitat, yaitu peta jarak dengan sungai, peta jarak dengan jalan, peta jarak dengan desa dan peta nilai NDVI (Normalized Difference Vegetation). Kemudian data titik sebaran atau peta distribusi orangutan diidentifikasi (Summarize zone) komponennya terhadap tiap layer dan dianalisis dengan menggunakan Analisis Komponen Utama (Principle Component Analysis/PCA) untuk mendapatkan nilai bobot pada masing-masing layer.

Hasil PCA digunakan untuk menentukan bobot masing faktor habitat dan untuk analisis spasial dengan persamaan sebagai berikut:

\section{$\mathrm{Y}=\mathrm{aFK} 1+\mathrm{bFk} 2+\mathrm{cFk} 3+\mathrm{dFk} 4+\mathrm{eFk} 5+\mathrm{fFk} 6$}

Selanjutnya dari model tersebut dilakukan skoring dengan rumus:.

\section{SKOR $=\Sigma \mathbf{\Sigma} \mathbf{W}{ }^{*} \mathbf{F k i}$}

Ket: $\quad$ SKOR = nilai dalam penetapan klasifikasi kesesuaian habitat; $\mathrm{Wi}=$ bobot untuk setiap parameter; Fki = faktor kelas dalam parameter

Hasil skoring tersebut, kemudian dilakukan klasifikasi berdasarkan sebaran nilai piksel dari hasil analisis spasial, dengan rumus:

$$
\text { Selang }=\frac{\text { Smaks }-S \min }{K}
$$

Ket: Selang = nilai dalam penetapan selang klasifikasi kesesuaian habitat; Smaks = nilai piksel tertinggi; Smin = nilai piksel terendah; $\mathrm{K}=$ banyaknya klasifikasi kesesuaian habitat. 
Dengan demikian nilai kesesuaian habitat orangutan kalimantan dirumuskan sebagai berikut:

$$
\begin{gathered}
\mathrm{KHn}=\begin{array}{r}
\mathrm{Smin}+\text { SELANG } \\
\text { dan/atau }
\end{array} \\
\mathrm{KH}=\mathrm{KHn}-1+\text { SELANG }
\end{gathered}
$$

Ket: $\mathrm{KHn}=$ nilai Kesesuaian Habitat ke-n; $\mathrm{Smin}=$ nilai skor terendah, $\mathrm{KHn}-1=$ nilai Kesesuaian Habitat sebelumnya; SELANG $=$ nilai dalam penetapan selang klasifikasi kesesuaian habitat.

$$
\text { Validasi }=\frac{n}{N} \times 100 \%
$$

Ket : Validasi $=$ persentase kepercayaan; $n$ $=$ jumlah titik pertemuan orangutan kalimantan yang ada pada satu klasifikasi kesesuaian; $\mathrm{N}=$ jumlah total titik pertemuan orangutan kalimantan hasil survey

\section{Hasil dan Pembahasan \\ Peta Tematik untuk Pembuatan Model Spasial.}

Pembangunan model spasial kesesuaian habitat orangutan kalimantan dilakukan dengan menganalisis penilaian kebutuhan hidup (life requisites) orangutan kalimantan terhadap faktor-faktor habitat dan faktor-faktor gangguan. Faktor-faktor habitat yang digunakan adalah ketersediaan air yang diwakilkan dengan jarak dengan sungai dan nilai NDVI (Normalization Difference Vegetation Index), sedangkan faktor-faktor gangguan berasal dari aktivitas manusia yang diidentifikasi melalui jarak dengan jalan dan jarak dengan desa.

Dari hasil survey di lapang didapatkan 72 titik sarang yang ditemukan dari ke empat lokasi pengambilan data yang terdiri dari 11 transect.

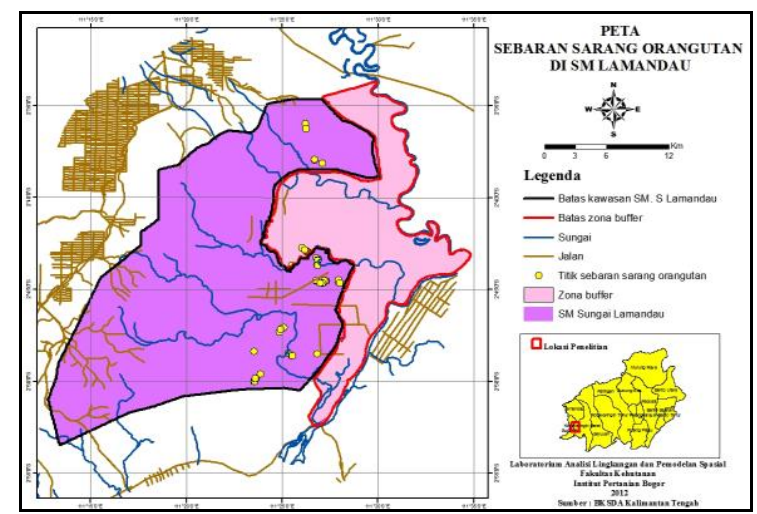

Gambar 1 Peta sebaran orangutan

\section{Peta Jarak dengan Sungai}

Hasil data survey dan kajian pustaka diketahui bahwa orangutan dari berbagai lokasi yang ada di Kalimantan maupun Sumatera lebih umum terdapat di dekat sungai-sungai kecil atau besar dan di dekat rawa-rawa (Mackinnon, 1972). Orangutan memenuhi kebutuhan pokok akan cairan melalui beberapa sumber salah satunya yaitu dari sungai (Napier \& Napier, 1985). Penentuan klasifikasi jarak dari sungai ditentukan pada jelajah harian orangutan. Galdikas (1988) menyatakan bahwa jelajah harian orangutan rata-rata orangutan menempuh jelajah harian $790 \mathrm{~m}$, sehingga selang setiap kelas kesesuaian untuk buffer ditetapkan sebesar 800 meter. Jarak dari sungai diklasifikasikan menjadi 5 kelas, yaitu 0-800 m, 800-1600 m, 1600$2400 \mathrm{~m}, 2400-3400 \mathrm{~m}$, dan lebih dari 3400 $\mathrm{m}$. Kelas $0-800 \mathrm{~m}$ memiliki luasan paling besar yaitu sebesar 27803,07 ha, kelas 800-1600m memiliki luasan 20996,82 ha, kelas 1600-2400 m memiliki luas sebesar 15659,61 ha, kelas 2400-3200m memiliki luas sebesar 8818,2 ha, dan kelas $>3200$ m memiliki luas sebesar 6741,81 ha. Jarak kurang dari sama dengan 800 meter dari sungai dianggap habitat yang sesuai untuk orangutan kalimantan. Peta jarak dengan sungai dapat dilihat pada Gambar 2

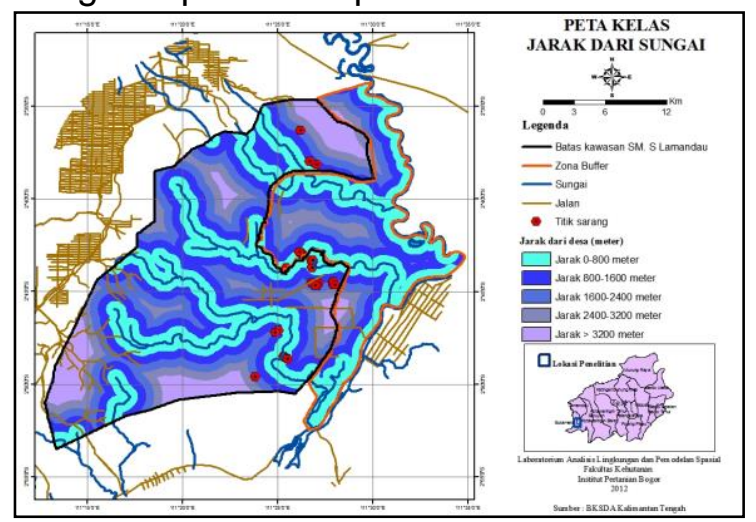

Gambar 2. Peta jarak dengan sungai

\section{a. Peta Nilai NDVI}

Keberadaan orangutan erat kaitannya dengan kondisi vegetasi. Tingkat kesesuaian habitat orangutan dinilai berdasarkan pada dua komponen biotik utama yakni ketersediaan pohon sarang dan pohon pakan dihabitatnya (Muin, 2007). Menurut Prayogo (2014) bahwa habitat yang memiliki kesesuaian tinggi 
bagi orangutan merupakan daerah yang memiliki tutupan lahan yang baik dan umumnya banyak dijumpai pohon sebagai sumber pakan orangutan. Kondisi vegetasi untuk analisis spasial habitat digunkan nilai NDVI. Perhitungan menggunakan NDVI ini umum dilakukan karena memiliki korelasi yang kuat dengan karakteristik vegetasi (Fitriana, 2011). Nilai NDVI di lokasi penelitian dibagi ke dalam 3 kelas, yaitu -1 - 0,0;0,0-0,25; dan lebih dari 0,25. Nilai NDVI -1-0 menunjukkan tutupan lahan berupa badan air, nilai 0-0,1 menunjukkan lahan terbuka, dan nilai $>0,1$ menunjukkan vegetasi. Luasan dari masing-masing kelas diketahui, kelas -1-0,0 memiliki luasan 2663,68 ha, kelas $0,0-0,25$ memiliki luasan paling kecil yaitu 15766,11 ha, dan kelas lebih dari 0,25 memiliki luasan paling besar yakni 37617,17 ha. Peta nilai NDVI disajikan pada Gambar 3.

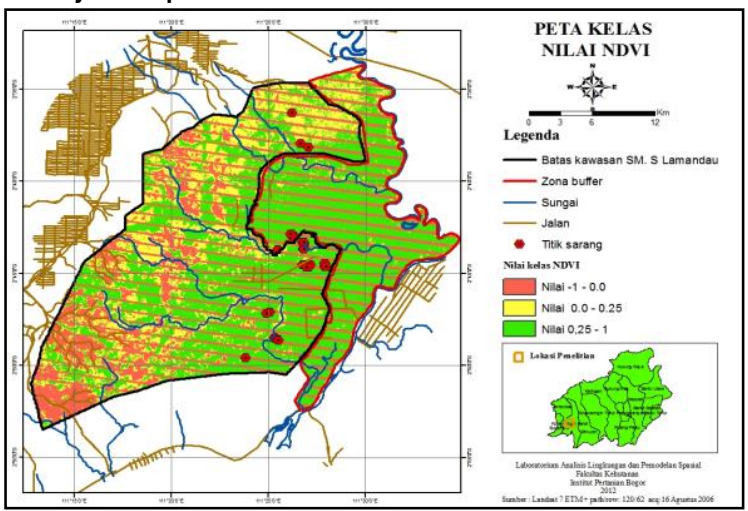

Gambar 3. Peta Nilai NDVI

\section{b. Peta Jarak dengan Jalan}

Jarak dengan jalan merupakan faktor gangguan yang digunakan dalam penyusunan model ini. Penurunan populasi orangutan tersebut terjadi karena tekanan masyarakat, baik tekanan terhadap habitat yang menjadi tempat tinggal maupun terhadap orangutan sendiri. Jalan dapat menjadi akses yang mempermudah adanya interaksi masyarakat dengan orangutan maupun dengan habitatnya yang mengakibatkan tekanan atau gangguan terhadap keberadaan orangutan. Pembagian kelas jarak dengan jalan dikelompokkan menjadi tiga kelas. Dasar yang digunakan dalam penentuan selang ini sama dengan penentuan selang kelas pada peta jarak dengan sungai yaitu 800 meter. Luasan masing-masing kelas jarak dengan jalan yaitu kelas $0-800 \mathrm{~m}$ memiliki luasan 16022,34 ha; 800-1600 m memiliki luasan 12680,91 ha; dan lebih dari $1600 \mathrm{~m}$ memiliki luasan 51315,66 ha. Peta jarak dari jalan di lokasi penelitian disajikan pada Gambar 4.

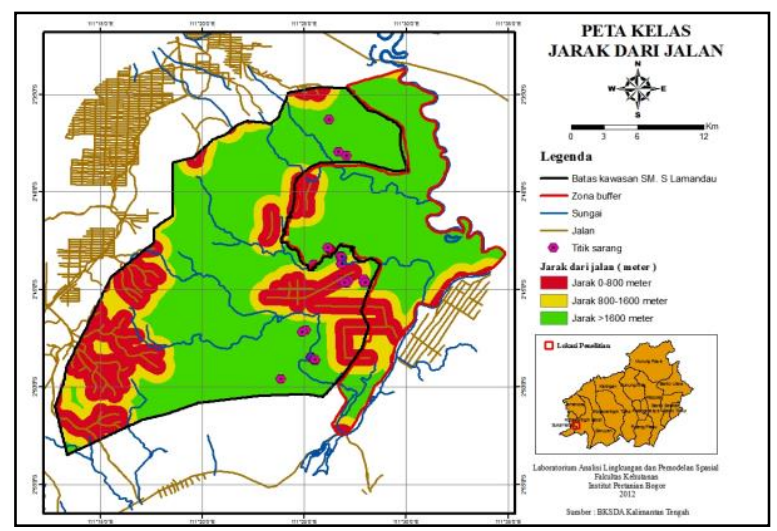

Gambar 4. Peta jarak dengan jalan

\section{c. Peta Jarak dengan Desa}

Keberadaan desa di sekitar lokasi penelitian sangat berpengaruh terhadap keberadaan orangutan. Semakin dekat dengan desa maka interaksi terhadap kawasan atau lokasi penelitian pun semakin tinggi. Semakin tinggi interaksi dengan kawasan maka keberadaan orangtuan pun semakin terancam. Dasar pengkelasan peta jarak dengan jalan yaitu wilayah jelajah harian terjauh yakni $3000 \mathrm{~m}$ (Galdikas, 1988). Peta jarak dari desa di meter bagi ke dalam lima kelas, yaitu 0$3000 \mathrm{~m}$ memiliki luasan 311,13ha, 3000$6000 \mathrm{~m}$ memiliki luasan 3822,3 ha, $6000-$ $9000 \mathrm{~m}$ memiliki luasan $11678,76 \mathrm{ha}, 9000-$ $12000 \mathrm{~m}$ memiliki luasan $18114,93 \mathrm{ha}$, dan lebih dari $12000 \mathrm{~m}$ memiliki luasan 46091,79 ha. Peta jarak dari jalan di lokasi penelitian disajikan pada Gambar 5.

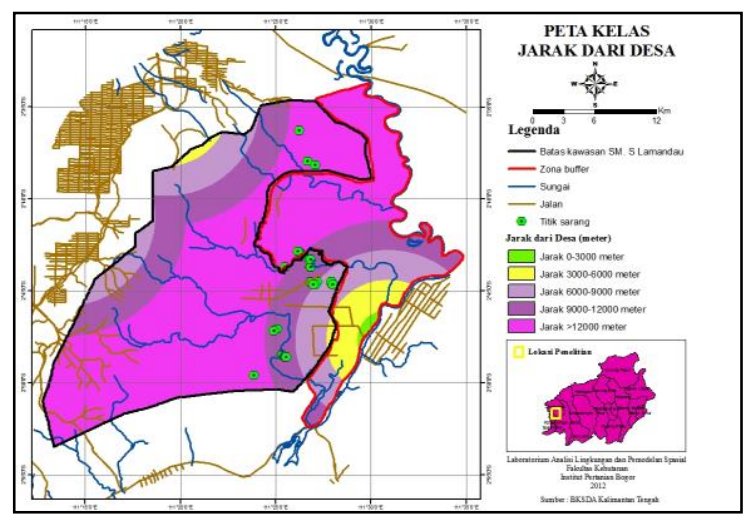

Gambar 5. Peta jarak dengan desa 


\section{2.b.Pembuatan Model Kesesuaian Habitat Orangutan Kalimantan}

Penentuan bobot untuk membangun model kesesuaian habitat orangutan kalimantan diperoleh dengan menggunakan Analisis Komponen Utama (Principal Componen Analysis/PCA) . Variabel yang digunakan meliputi jarak dengan sungai, nilai NDVI, jarak dengan jalan dan jarak dengan desa. Data yang digunakan pada PCA adalah data titik penemuan sarang orangutan kalimantan yang dianalisis posisinya secara spasial terhadap empat variabel tersebut. Hasil PCA menunjukkan bahwa terdapat dua pengelompokan variabel baru (komponen utama) dari 4 variabel sebagai pembangun model kesesuaian habitat orangutan. Hasil analisis faktor dari prosedur PCA diperoleh nilai total varian/ keragaman yang dapat dijelaskan sebesar 74,051 \% dengan jumlah matriks komponen (vektor ciri) sebanyak dua komponen. Besarnya keragaman faktor satu yang mampu diterangkan adalah sebesar 43,664 \%, sedangkan keragaman faktor dua adalah $30,386 \%$. Pemilihan komponen 1 dan 2 disebabkan memiliki nilai eigenvalue $>1$ seperti pada Tabel 1:

Tabel 1.Keragaman Total Komponen Utama

\begin{tabular}{cccc}
\hline $\begin{array}{c}\text { Komponen } \\
\text { Utama }\end{array}$ & \multicolumn{3}{c}{ Akar Ciri } \\
\cline { 2 - 4 } & Total & $\begin{array}{c}\text { \% } \\
\text { Keragaman }\end{array}$ & $\begin{array}{c}\text { Kumulatif } \\
\text { Keragaman } \\
\text { \% }\end{array}$ \\
\hline 1 & $\mathbf{1 , 7 4 7}$ & 43,664 & 43,664 \\
2 & $\mathbf{1 , 2 1 5}$ & 30,386 & $\mathbf{7 4 , 0 5 1}$ \\
3 & 0,600 & 15,008 & 89,059 \\
4 & 0,438 & 10,941 & 100,00 \\
\hline
\end{tabular}

Bobot dari masing-masing variabel untuk membangun model kesesuaian habitat orangutan kalimantan didapatkan dari skor total PCA masing-masing komponen utama yang memiliki hubungan positif dengan variabel pemodelan kesesuaian habitat (Herdiyanti, 2009). Dari hasil analisis di atas menunjukkan bahwa terdapat dua variabel yang memiliki hubungan positif dengan nilai tertinggi terhadap komponen pertama yaitu jarak dengan sungai dan nilai NDVI. Sedangkan untuk komponen ke dua terdapat dua variabel yang mempunyai hubungan positif dengan nilai tertinggi. Jarak dari jalan dan jarak dari desa memiliki hubungan positif dengan komponen ke dua. Keeratan hubungan antara keempat variabel habitat dengan komponen utama ditunjukkan oleh vektor ciri PCA yang disajikan dalam Tabel 2.

Tabel 2. Vektor ciri variabel PCA

\begin{tabular}{llcc}
\hline No & \multicolumn{1}{c}{ Variabel } & \multicolumn{2}{c}{ Komponen } \\
\cline { 3 - 4 } & & $\mathbf{1}$ & $\mathbf{2}$ \\
\hline 1 & Jarak dari sungai & $\mathbf{0 , 8 3 2}$ & 0,207 \\
2 & NDVI & $\mathbf{0 , 7 8 6}$ & 0,055 \\
3 & Jarak dari jalan & $-0,636$ & $\mathbf{0 , 5 9 0}$ \\
4 & Jarak dari desa & 0,177 & $\mathbf{0 , 9 0 7}$ \\
\hline
\end{tabular}

Dengan hasil pembobotan terebut maka model kesesuaian habitat orangutan kalimantan dirumuskan sebagai berikut:

$$
\begin{gathered}
Y=(1,747 \times \text { FK Sungai })+(1,747 \\
\times F k \text { NDVI })+(1,215 \times \text { Fk Jalan })+ \\
(1,215 \times \text { FK Desa })
\end{gathered}
$$

Keterangan :

$$
\begin{aligned}
& \mathrm{Y} \quad=\text { model kesesuaian habitat } \\
& \text { FK sungai = skor kesesuaian jarak dari } \\
& \text { jalan } \\
& \mathrm{Fk}_{\mathrm{NDVI}}=\text { skor kesesuaian NDVI } \\
& \mathrm{Fk} \text { Jalan }=\text { skor kesesuaian jarak dari } \\
& \text { jalan } \\
& \text { Fk Desa = skor kesesuaian jarak dari } \\
& \text { desa }
\end{aligned}
$$

\section{2.c Peta Kesesuaian Habitat Orangutan Kalimantan}

a. Pembuatan Peta Kesesuaian Habitat Orangutan Kalimantan

Hasil analisis spasial dengan metode pembobotan, pengkelasan, dan pengharkatan/ skoring dan tumpang tindih (overlay) menghasilkan nilai pixel terendah adalah 5,924 dan nilai pixel tertinggi yaitu 23,696. Dalam menentukan kelas kesesuaian habitat orangutan kalimantan, maka harus menentukan selang untuk setiap indeks kesesuaian habitat. Selang dalam setiap IKH didapat dengan membagi rata antara selisih piksel tertinggi dengan piksel terendah dengan jumlah kelas kesesuaian. Sehingga didapatkan nilai dari 
indeks kesesuaian rendah (IKH1) yaitu berada pada selang 5,924 s.d 11,939, indeks kesesuaian sedang (IKH 2) berada pada selang 11,939 s.d 17,924 dan indeks indeks kesesuaian tinggi (IKH 3) berada pada selang 17,924 s.d 23,696.

Habitat orangutan kalimantan di SM Sungai Lamandau dengan kesesuaian habitat tinggi memiliki luasan 21328,6 ha atau $26,65 \%$ dari seluruh lokasi penelitian. Untuk kesesuaian sedang memiliki luasan terbesar yaitu 52378,7 ha dari seluruh lokasi penelitian atau $65,46 \%$ dari seluruh luasan lokasi penelitian. Sedangkan untuk kelas kesesuaian rendah memiliki luasan terkecil yaitu sebesar 6311,7 ha atau $7,88 \%$ dari seluruh lokasi penelitian. Rahmat (2012) menyatakan bahwa model spasial habitat bukanlah upaya yang pasti untuk memprediksi ada tidaknya satwa pada suatu habitat, akan tetapi merupakan upaya untuk mengidentifikasi area yang harus diprioritaskan dalam pengelolaannya. Peta kesesuaian habitat orangutan kalimantan dapat dilihat pada Gambar 6.

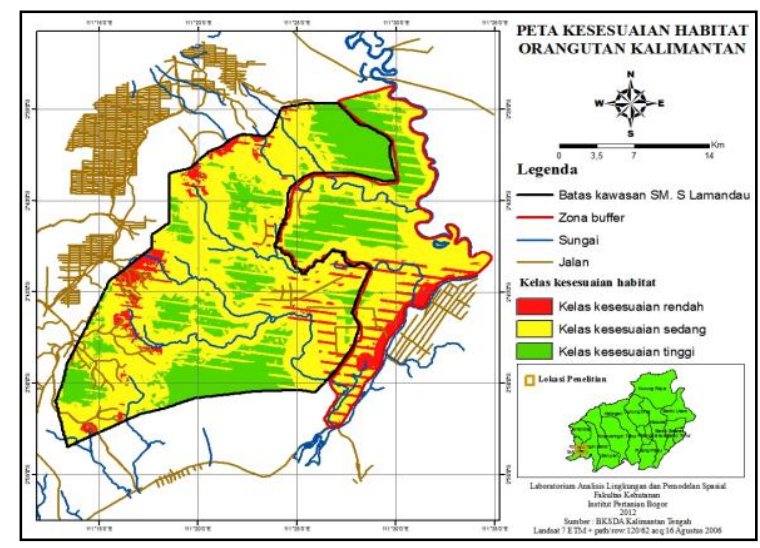

Gambar 6 Peta kesesuaian habitat orangutan kalimantan di SM Sungai Lamandau

\section{b. Validasi Model}

Validasi model digunakan untuk mengetahui tingkat kepercayaan terhadap model yang dibagun. Model yang telah dibangun dapat diterima apabila hasil validasi memperoleh tingkat kepercayaan yang tinggi yaitu $>85 \%$ pada kelas kesesuaian sedang dan tinggi. Hasil validasi menunjukkan bahwa model kesesuaian habitat orangutan kalimantan yang dibangun dapat diterima $100 \%$ pada kelas kesesuaian sedang dan tinggi. Pada kelas kesesuaian tinggi memiliki nilai validasi $39,13 \%$, pada kelas kesesuaian sedang memiliki nilai validasi $60,87 \%$ dan kelas kesesuaian rendah memiliki nilai $0 \%$. Berdasarkan hasil validasi yang diperoleh menunjukkan bahwa model yang dibangun cukup representatif untuk menunjukkan daerah kesesuaian habitat orangutan kalimantan. Namun, dilihat dari tingginya nilai validasi pada kelas kesesuaian sedang dibandingkan dengan kelas kesesuaian tinggi menunjukkan bahwa model yang diterima belum memberikan hasil yang optimal. Hal ini disebabkan terbatasnya waktu penelitian menjadikan sebaran orangutan kalimantan tidak merata di seluruh lokasi penelitian. Selain itu, masih terdapatnya komponen habitat orangutan kalimantan yang lain yang berpengaruh selain empat komponen yang digunakan dalam pembangunan model tersebut. Keempat komponen habitat yang digunakan dalam pembangunan model masih belum mewakili komponen habitat yang sensitif dan yang sangat diperlukan oleh orangutan Kalimantan karena tidak semua variabel bisa dijadikan layer dalam pengolahan dengan GIS. Osborne et al. (2001) menyebutkan bahwa model-model yang menggunakan peubah prediktor yang berasal atau berupa layer GIS sangat dibatasi oleh ketersediaan layer-layer data tersebut.

\section{c. PENUTUP}

\section{a. Kesimpulan}

Model spasial kesesuaian habitat orangutan kalimantan ( Pongo pygmaeus wurmbii, Linneaus 1760) yang dihasilkan pada penelitian ini adalah

$Y=(1,747 \times$ FK Sungai $)+(1,747 \times$ Fk NDVI $)+$
$(1,215 \times$ Fk Jalan $)+(1,215 \times$ Fk Desa $)$
Habitat orangutan kalimantan di Suaka Margasatwa Sungai Lamandau dengan kesesuaian habitat tinggi memiliki luasan 21328,6 ha. Luasan tersebut mencakup 26,65\% dari seluruh lokasi penelitian. Untuk kesesuaian sedang memiliki luasan terbesar yaitu 52378,7 ha, atau mencakup $65,46 \%$ dari seluruh luasan lokasi penelitian. Sedangkan untuk kelas kesesuaian rendah memiliki luasan terkecil yaitu sebesar 6311,7 ha atau $7,88 \%$ dari seluruh lokasi penelitian. Model kesesuaian habitat orangutan kalimantan dapat 
diterima dengan validasi $39,13 \%$, pada kelas kesesuaian tinggi, $60,87 \%$ pada kelas kesesuaian sedang dan kelas kesesuaian rendah memiliki nilai $0 \%$.

\section{SIMPULAN}

Model spasial kesesuaian habitat orangutan kalimantan ( Pongo pygmaeus wurmbii, Linneaus 1760) yang dihasilkan pada penelitian ini adalah

$\begin{aligned} & Y=(1,747 \times \text { FK Sungai })+(1,747 \times \text { FK NDVI })+ \\ &(1,215 \times \text { FK Jalan })+(1,215 \times \text { FK Desa })\end{aligned}$

Habitat orangutan kalimantan di Suaka Margasatwa Sungai Lamandau dengan kesesuaian habitat tinggi memiliki luasan 21328,6 ha. Luasan tersebut mencakup 26,65\% dari seluruh lokasi penelitian. Untuk kesesuaian sedang memiliki luasan terbesar yaitu 52378,7 ha, atau mencakup $65,46 \%$ dari seluruh luasan lokasi penelitian. Sedangkan untuk kelas kesesuaian rendah memiliki luasan terkecil yaitu sebesar 6311,7 ha atau $7,88 \%$ dari seluruh lokasi penelitian. Model kesesuaian habitat orangutan kalimantan dapat diterima dengan validasi $39,13 \%$, pada kelas kesesuaian tinggi, $60,87 \%$ pada kelas kesesuaian sedang dan kelas kesesuaian rendah memiliki nilai $0 \%$

\section{UCAPAN TERIMAKASIH}

Penulis mengucapkan terimakasih dan penghargaan kepada Orangutan Foundation UK (OF-UK) yang telah memfasilitasi kegiatan selama studi dilakukan. Penulis juga mengucapkan terimakasih BKSDA Kalimantan Tengah yang telah memberikan izin untuk kegiatan penelitian.

\section{DAFTAR PUSTAKA}

Anthony, Nayman J. 1978. World of wildlife. New York: Fact on File

Fitriana, F. 2011. Pemodelan Spasial Kesesuaian Habitat Orangutan Kalimantan (Pongo pygmaeus wurmbii, Linneaus 1760) di Suaka Margastawa Sungai Lamandau Kalimantan Tengah [skripsi]. Bogor (ID): Institut Pertanian Bogor

Fitriana F, Prasetyo LB, Kartono AP. 2016. Habitat Preferensial Tarsius Belitung (Cephalopachus bancanus saltator
Elliot, 1910). Media Konservasi 21(2):174-182.

Galdikas BMF. 1988. Orangutan diet, range, and activity at Tanjung Puting, Central Borneo. Int J Primatol 9 (1): 1-35.

Herdiyanti PR. 2009. Pemetaan kesesuaian habitat rafflesia patma blume di cagar alam leuweung sancang garut jawa barat [skripi]. Bogor: Jurusan Konservasi Sumberdaya Hutan, Fakultas Kehutanan. Institut Pertanian Bogor.

MacKinnon, J.R. 1972. The Behaviour and Ecology of the Orang-Utan (Pongo pygmaeus), with Relation to the Other Apes [Thesis]. Oxford : University of Oxford. tidak dipublikasikan.

Muin A. 2007. Analisis tipologi pohon tempat bersarang dan karakteristik sarang orangutan (Pongo pygmaeus wurmbii Groves, 2001) di Taman Nasional Tanjung Putting Kalimantan. Bogor (ID): Institut Pertanian Bogor

Napier JR dan Napier PH. 1985. The Natural History of The Primates. Great Britain: MIT Press.

Osborne PE, Alonso JC, Bryant RG. 2001. Modelling landscape scale habitat use using GIS and remote sensing: A case study with Great Bustards. J Appl Ecol 38: 458-471. DOI:10.1016/j.geomorph.2012.04.00 4

Primack, R.B. ; J. Supriatna ; M. Indrawan ; P. Kramadibrata. 1998. Biologi Konservasi. Yayasan Obor Indonesia. Jakarta

Prayogo H. 2014. Pendugaan kesesuaian habitat orangutan Kalimantan (Pongopygmaeus pygmaeus) dan karakteristik genetiknya di Kabupaten Kapuas Hulu Kalimantan Barat [tesis]. Bogor (ID): Institut Pertanian Bogor

Rahmat UM. 2012. Sebaran spasial dan model kesesuaian habitat badak jawa (Rhinoceros sondaicus Desmarest, 1822) di Taman Nasional Ujung Kulon [desertasi]. Bogor (ID): Institut Pertanian Bogor

Sosilawaty, Rizal M, Saragih NF. 2020. Keanekaragaman dan Karakteristik Pohon Bersarang Orangutan (Pongo 
Agroprimatech

Vol. 5 No. 1, Oktober 2021

e-ISSN :2599-3232

pygmaeus wurmbii) di Suaka Margasatwa Lamandau Kalimantan Tengah. Jurnal Penelitian Kehutanan Bonita 2(1):1-10 